\title{
Virulence-associated genes and antibiotic resistance patterns of Vibrio spp. isolated from cultured marine fishes in Malaysia
}

Nurliyana Mohamad', Mohammad Noor Azmai Amal ${ }^{1,4^{*}}$ (D), Mohd Zamri Saad ${ }^{2,4}$, Ina Salwany Md Yasin ${ }^{3,4}$, Nor Amalina Zulkiply ${ }^{3}$, Muskhazli Mustafa $^{1}$ and Nurrul Shaqinah Nasruddin ${ }^{5}$

\begin{abstract}
Background: Vibriosis is an important bacterial disease of cultured marine fishes worldwide. However, information on the virulence and antibiotic resistance of Vibrio spp. isolated from fish are scarce. This study investigates the distribution of virulence associated genes and antibiotic resistance patterns of Vibrio spp. isolated from cagecultured marine fishes in Malaysia.

Results: A total of 63 Vibrio spp. isolated from 62 cultured marine fishes in various geographical regions in Peninsular Malaysia were analysed. Forty-two of the isolates (66.7\%) were positive for all chiA, luxR and vhpA, the virulence genes produced by pathogenic $V$. harveyi. A total of 62 Vibrio isolates (98\%) had th gene of $V$. parahaemolyticus, while flaC gene of $V$. anguillarum was detected in 43 of isolates (68\%). Other virulence genes, including $t d h$, trh, hlyA and tox $R_{v c}$ were absent from any of the isolates. Multiple antibiotic resistance (MAR) was exhibited in all strains of Harveyi clade, particularly against ampicillin, penicillin, polypeptides, cephems and streptomycin. The MAR index ranged between 0.06 and 0.56, and $75 \%$ of the isolates have MAR index of higher than 0.20 . Host species and geographical origin showed no correlation with the presence of virulence genes and the antibiotic resistance patterns of Vibrio spp.

Conclusions: The study indicates that majority of Vibrio spp. isolated from cultured marine fishes possess virulence genes, but were not associated with human pathogen. However, the antibiotics resistance is a real concern and warrants ongoing surveillance. These findings represent an updated knowledge on the risk of Vibrio spp. to human health, and also provides valuable insight on alternative approaches to combat vibriosis in cultured fish.
\end{abstract}

Keywords: Vibrio, Cultured fish, Virulence genes, Multiple antibiotics resistance

\footnotetext{
*Correspondence: mnamal@upm.edu.my

'Department of Biology, Faculty of Science, Universiti Putra Malaysia, 43400

UPM Serdang, Selangor, Malaysia

${ }^{4}$ Laboratory of Marine Biotechnology, Institute of Bioscience, Universiti Putra

Malaysia, 43400 UPM Serdang, Selangor, Malaysia

Full list of author information is available at the end of the article
}

(c) The Author(s). 2019 Open Access This article is distributed under the terms of the Creative Commons Attribution 4.0 International License (http://creativecommons.org/licenses/by/4.0/), which permits unrestricted use, distribution, and reproduction in any medium, provided you give appropriate credit to the original author(s) and the source, provide a link to the Creative Commons license, and indicate if changes were made. The Creative Commons Public Domain Dedication waiver (http://creativecommons.org/publicdomain/zero/1.0/) applies to the data made available in this article, unless otherwise stated. 


\section{Background}

Vibrio spp. that have been associated with diseases in animals and human often possess virulence factors, which are not available or present in the environmental Vibrio [1]. However, since Vibrio possesses highly plastic genome, the probability of horizontal transfer of the virulence genes between pathogenic and environmental Vibrio is high. This contributes to the increased number of pathogenic Vibrio strains in aquatic environment [2]. Recently, more disease outbreaks following infections by Vibrio harveyi, $V$. alginolyticus, $V$. parahaemolyticus and $V$. campbellii in farmed fishes were reported in many tropical countries [3-6].

Several extracellular products that are known to contribute to the virulence of Vibrio include proteases, hemolysins, phospholipases, siderosphores, cytotoxins, biofilm formation, quorum sensing, and presence of phage [7-9]. Swarming motility of Vibrio has been consistently associated with their virulence [10], while hemolysin is a common virulence factor reported in Vibrio associated with both fish and human diseases [11]. In addition, virulence of several pathogenic Vibrio has also been attributed to quorum-sensing, the bacterial cell to cell communication [12].

Resistance to the bactericidal mechanisms is another important contributor to the virulence of fish pathogen. In the past few decades, antimicrobial resistance has emerged and evolved in Vibrio spp. due to the excessive use of antibiotics in human medicine, agriculture and aquaculture systems [13]. This issue gained great concern due to the increased resistance of pathogenic $V$. parahemolyticus, $V$. harveyi and $V$. vulnificus towards many clinically used antimicrobials [14-18]. Moreover, multiple antibiotic resistance (MAR) strains of $V$. harveyi and $V$. alginolyticus have caused severe economic setbacks to the aquaculture industry [19].

This study described the presence of virulence-associated genes and antibiotic resistance patterns of Vibrio spp. within the Harveyi clade, which were isolated from various aquaculture areas in Peninsular Malaysia. Three typical virulence genes that were possessed by $V$. harveyi (chiA, luxR and $v h p A$ ) and five atypical virulence genes that contributed to pathogenic Vibrio of both fish and human (flaC, $h l y A$, tox $R_{v c}$, $t d h$ and $\left.t r h\right)$ were targeted. Furthermore, thermolabile hemolysin gene th, a species specific marker for $V$. parahaemolyticus was also included. In addition, resistance of the isolates towards 16 commercial antibiotics of various groups were determined to evaluate the potential responsiveness to the suite of antibiotic treatments that most frequently used in aquaculture.

\section{Results}

Generally, five out of the nine targeted virulence genes were present in the tested isolates (Fig. 1a). All (100\%) 63 isolates of Harveyi clade possessed typical virulence genes of chiA and $\operatorname{luxR}$. Forty-two isolates (67\%) of studied Harveyi clade and all (100\%) $\mathrm{V}$. campbellii isolates were positive of $v h p A$ gene. However, only two out of six virulence genes were detected in other Vibrio spp. tested in this study. The $t$ th was detected in all isolates except an isolate of $V$. campbellii.

The flaC gene was detected in $68 \%$ of the isolates (Fig. 1b). All $V$. harveyi and $V$. parahaemolyticus that were isolated from Pulau Ketam were positive for flaC. However, they lack the $t d h, t r h, h l y A$ and $t o x R_{\mathrm{vc}}$ genes. Moreover, 27 (43\%) of the isolates carried all the virulence genes of $\operatorname{chiA}, \operatorname{lux} R, v h p A$, flaC and th, including all $V$. campbellii that were isolated from Pulau Ketam, and two V. parahaemolyticus from Banting. However, there was no correlation between the presence of virulence genes and the source of the isolates.

Amplification of $\operatorname{chiA}, \operatorname{luxR}, \operatorname{vhpA}$, flaC and th from all species of Vibrio isolates, yielded products of approximately $232 \mathrm{bp}, 618 \mathrm{bp}, 201 \mathrm{bp}, 580 \mathrm{bp}$, and $450 \mathrm{bp}$, respectively (Fig. 2). Figure 3 shows the phylogenetic tree of the virulence genes. Sequence analysis revealed that the chiA of $V$. campbellii GRO 230-L1 and $V$. harveyi SNA 143-L1 shared 99 and $89 \%$ similarity, respectively with chiA of $V$. harveyi, while $V$. alginolyticus SEA $124-S$ and $V$. parahaemolyticus GRO 286-E1 showed 95-99\% similarity with chitinase A from $V$. parahaemolyticus [AF323471]. The luxR of $V$. harveyi SEA 131-K1, V. campbellii SEA 178-K1 and $V$. parahaemolyticus GRO 180-K1 were $>98 \%$ similar with $l u x R$ of $V$. harveyi. However, luxR of $V$. alginolyticus SNA 212-S1 was identical (99\%) to luxR of $V$. alginolyticus [EF596781]. All $\nu h p A$ in this study shared high similarity (>98\%) with $v h p A$ of $V$. harveyi. Similarly, high similarity (> $89 \%)$ was also observed between th of Vibrio isolates in this study and th of $V$. parahaemolyticus JPW-8-11-1. In addition, flaC of $V$. harveyi SNA 143-L1 and $V$. alginolyticus GRO 144-E1 were highly identical (99\%) with flaA of $V$. alginolyticus HY9901. On the other hand, flaC of $V$. parahaemolyticus shared $99 \%$ similarity with flaA of $V$. parahaemolyticus ATCC 17802, while flaC of $V$. harveyi SNA 143-L1 shared $96 \%$ with flaB of $V$. harveyi VIB645.

The antibiotic resistance patterns are illustrated in Fig. 4. Highest resistance (79 to 99\%) was observed against penicillin and the polypeptides group of antibiotics. All Vibrio spp. isolated from Pulau Ketam, with the exception of one isolate of $V$. alginolyticus 

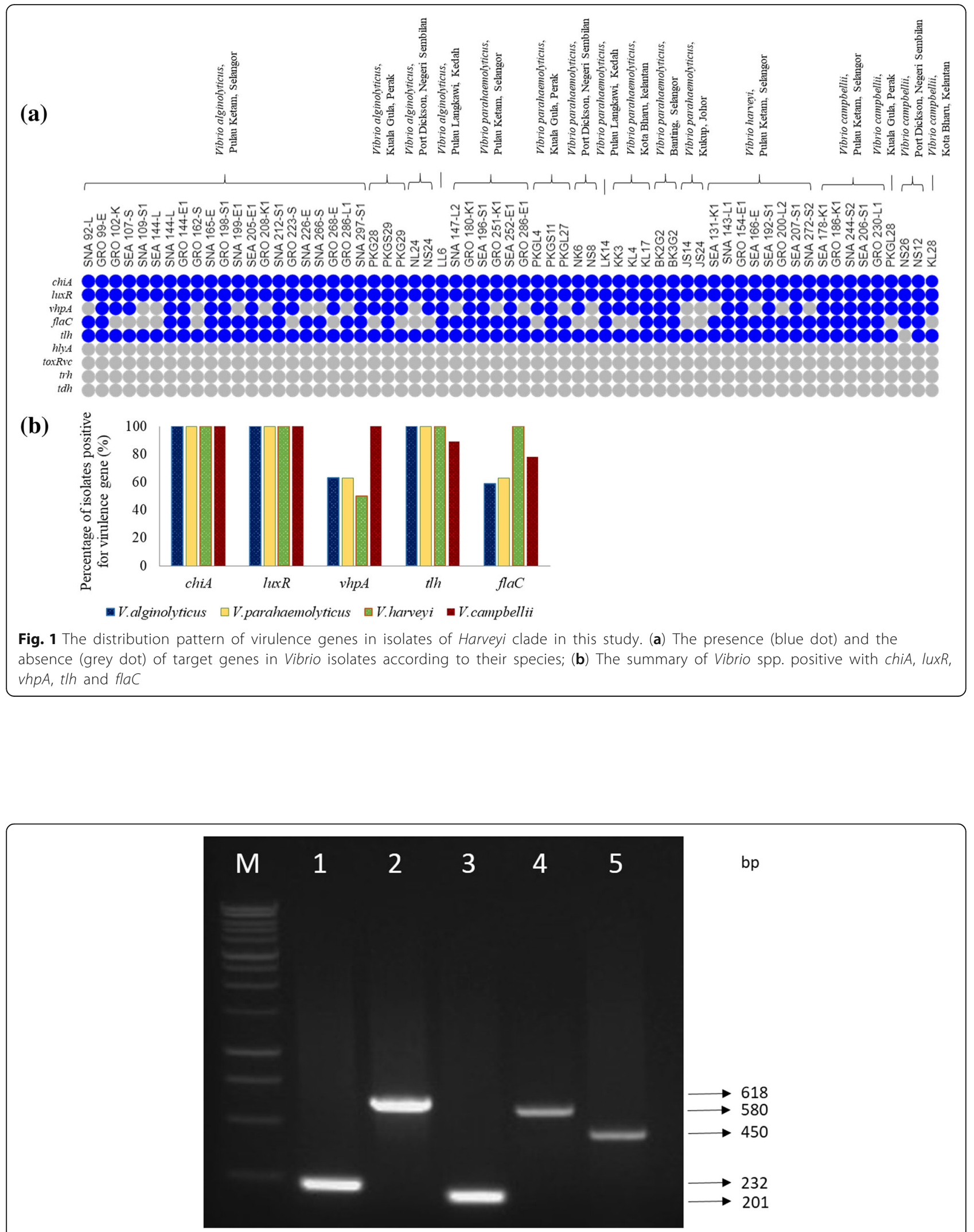

Fig. 2 Presence of the chiA, luxR, vhpA and flaC of $V$. anguillarum and th of $V$. parahaemolyticus in isolates of Harveyi clade. Lane M: $1 \mathrm{~kb}$ DNA ladder; Lane 1: chiA (232 bp); Lane 2: luxR (618 bp); Lane 3: vhpA (201 bp); Lane 4: flaC (580 bp) and Lane 5: th (450 bp) 


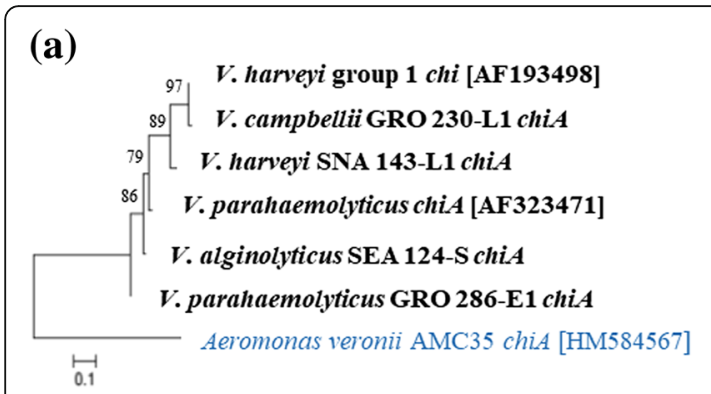

(c)

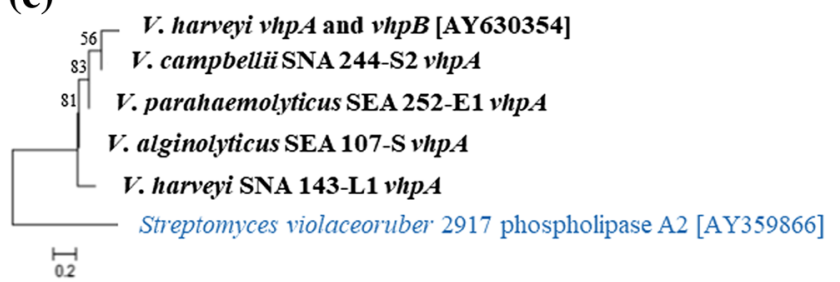

(b)

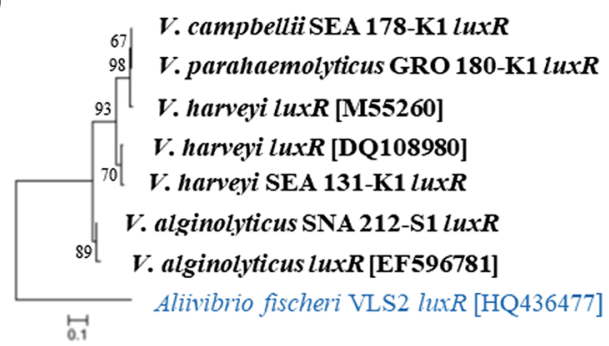

(d)

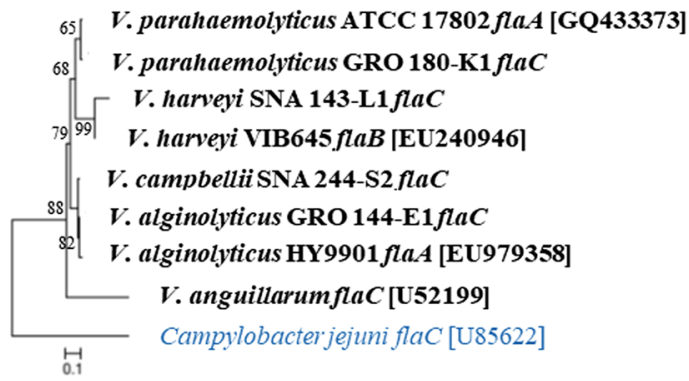

(e)

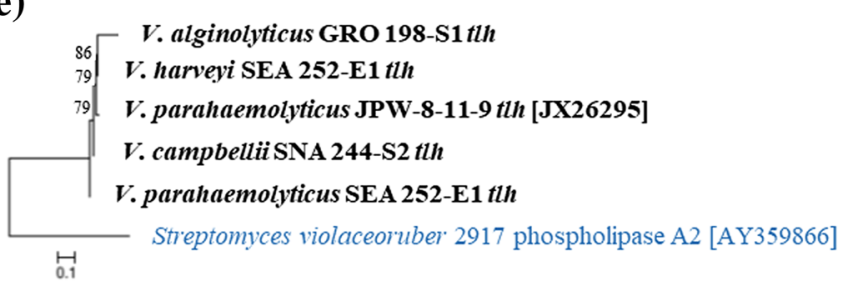

Fig. 3 Neighbour-joining tree (Kimura 2-parameter model) of (a) chiA (b) luxR (c) vhpA (d) flaC (e) th gene sequences from representative Vibrio isolates in this study. Reference sequences acquired from the NCBI GenBank are marked with their accession numbers. Strains in blue colour served as outgroup

and $V$. harveyi were resistance against AMP, $\mathrm{P}$ and VA. This was also exhibited by all $V$. campbellii isolates, regardless of their geographical origin. On the other hand, sensitivity towards AMP was mostly observed in $V$. parahaemolyticus isolated from Perak, Kedah, Kelantan and Johor. High resistance towards E was also observed in this study, where only $9 \%$ of the isolates showed sensitivity towards E.

A total of 60 and $46 \%$ of isolates were resistance against at least one antibiotic from cephems and aminoglycosides groups. Lower resistance level was observed for $\mathrm{CN}, \mathrm{K}$ and FEP, with less than $6 \%$ resistant isolates. However, more than $40 \%$ of the tested isolates were resistant against CTX, KF and S. The resistance against CTX was mostly showed by $V$. campbellii (78\%), followed by $V$. harveyi (63\%) and $V$. alginolyticus (62\%). Low resistance (8\%) towards quinolones group of antibiotic was observed in this study where none of $V$. alginolyticus and $V$. harveyi isolate was resistant towards CIP and NA. In addition, only one and seven isolates were resistant to $\mathrm{C}$ and SXT, respectively. None of the isolate in this study was resistant against $\mathrm{F}$ and TE.

The MAR index denotes the extent of environmental contamination by antimicrobial agents which potentially harmful to human health [20]. A MAR index higher than 0.2 indicated high-risk exposure to antibiotics. In this study, the MAR index ranged between 0.06 and 0.56 . Approximately $75 \%$ of the isolates showed MAR index of higher than 0.20, including 80\% from Pulau Ketam. However, no clear pattern was observed between the MAR index and the geographical origin. Nevertheless, an isolate of $V$. harveyi and two isolates of $V$. parahaemolyticus showed resistance against the nine antibiotics tested, with MAR index of 0.56. Among the three isolates, $V$. parahaemolyticus (GRO 286-E1) isolated from Pulau Ketam exhibited strongest resistance towards antibiotics tested, where only two antibiotics (TE and F) can inhibit the growth of this isolate. 


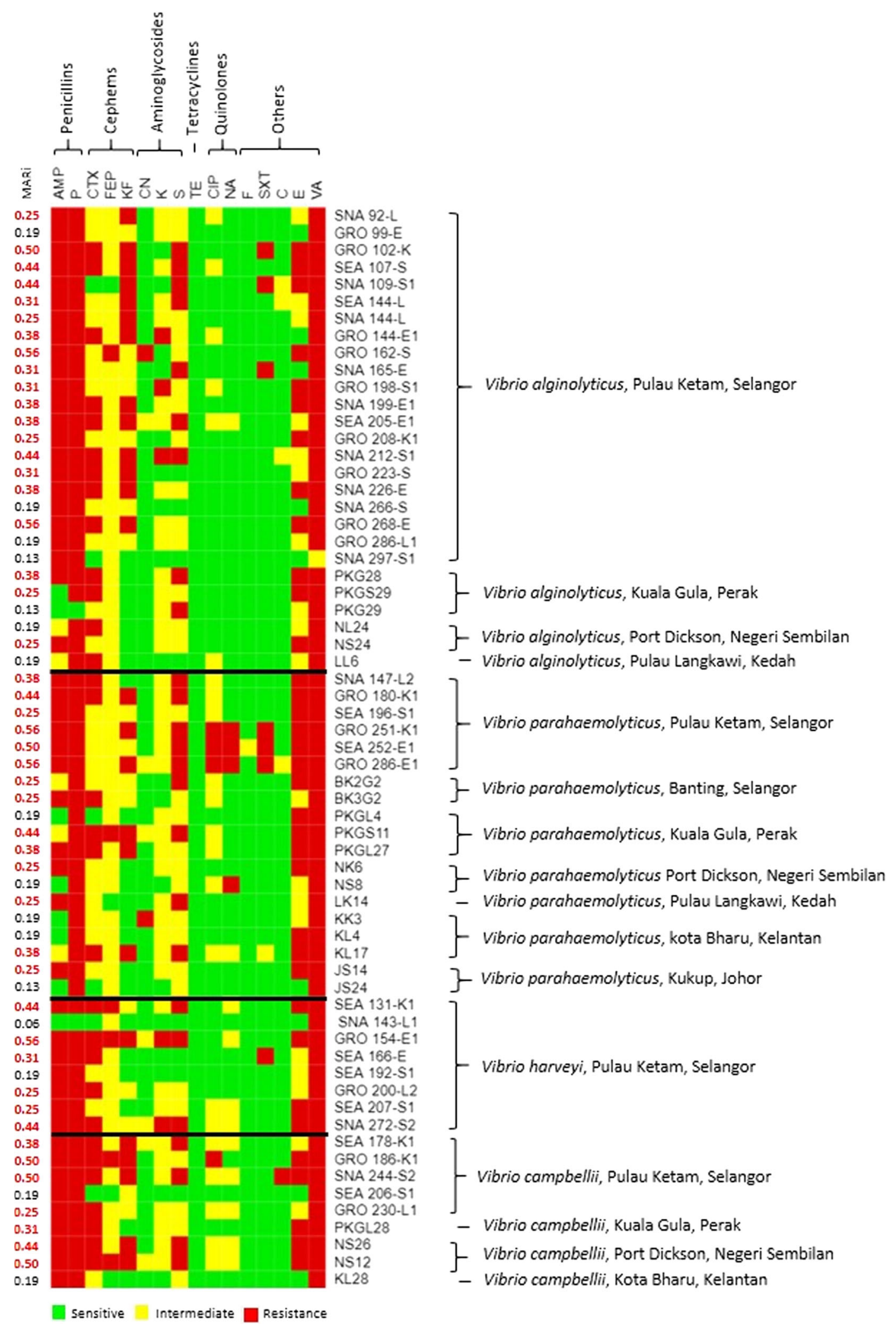

Fig. 4 (See legend on next page.) 
(See figure on previous page.)

Fig. 4 Antibiotic resistance patterns showed by isolates of Harveyi clades isolated from sampled fishes. MAR index (MARi) indicated the multiple antibiotics resistance index for the isolates. AMP: Ampicillin $(10 \mu \mathrm{g})$, P: Penicillin G $(10$ unit), CTX: Cefotaxime $(30 \mu \mathrm{g})$, FEP: Cefepime $(30 \mu \mathrm{g})$, KF: Cephalothin $(30 \mu \mathrm{g}), \mathrm{CN}$ : Gentamycin $(10 \mu \mathrm{g}), \mathrm{K}$ : Kanamycin $(30 \mu \mathrm{g})$, S: Streptomycin $(10 \mu \mathrm{g})$, TE: Tetracycline $(30 \mu \mathrm{g}), \mathrm{CIP}$ : Ciprofloxacin $(5 \mu \mathrm{g}), \mathrm{NA}$ : Nalidixic acid $(30 \mu \mathrm{g})$, F: Nitrofurantoin $(300 \mu \mathrm{g})$, SXT: Sulfamethoxazole/trimethoprim $(1.25 / 23.75 \mu \mathrm{g})$, C: Chloramphenicol $(30 \mu \mathrm{g})$, E: Erythromycin $(15 \mu \mathrm{g}), \mathrm{VA}:$ Vancomycin $(30 \mu \mathrm{g})$

\section{Discussion}

This study examines two factors that contribute to the pathogenicity of Vibrio spp., which previously isolated from cultured marine fishes in selected important farms and hatcheries in Peninsular Malaysia; the presence of virulence genes associated with pathogenic strains and the antibiotics resistance of Vibrio spp.

Virulence genes including chiA, $\operatorname{lux} R, \operatorname{tox} R_{v h}, v h p A$, serine protease and $v h h$ were widely distributed among pathogenic $V$. harveyi [21]. The distribution of these virulence genes in the closely related species of $V$. harveyi has also been documented [7]. In agreement to previous studies, chiA and $\operatorname{lux} R$ were found to presence in all isolates of Harveyi clade analysed in present study.

On the other hand, typical virulence gene of $v h p A$ was observed in $>50 \%$ of the isolates in this study, with $100 \%$ prevalence in $V$. campbellii isolates. Even though $v h p A$ was reported as a typical virulence gene harboured by $V$. harveyi, only $50 \%$ of our $V$. harveyi isolates was positive for this gene. Ruwandeepika et al. [21], reported a $100 \%$ prevalence of $v h p A$ among $V$. harveyi but conversely, $v h p A$ was reported to be absent in all $V$. harveyi isolated from diseased cultured fish in China, regardless of the virulence level $[2,19]$.

Studies demonstrated that the presence of chitinase and metalloprotease in ECP of Vibrio can cause disease in wide range of aquatic animals including fish, oyster and shrimp [7, 22]. In addition, quorum sensing was reported to regulate the production of these ECP and other virulence genes in Gram-negative fish pathogens [12]. For instance, Defoirdt [23] described on the virulence of $V$. harveyi controlled by quorum sensing. Another study by Croxatto et al. [24] demonstrated the involvement of quorum sensing in the secretion of metalloprotease EmpA and biofilm formation in $V$. anguillarum.

In this study, flaC was widely distributed in $60 \%$ of $V$. alginolyticus, $63 \%$ of $V$. parahaemolyticus, and $78 \% \mathrm{~V}$. campbellii isolates. In addition, all $V$. harveyi harboured flaC gene. In a study conducted by Bai et al. [25], 37.5\% of the $V$. harveyi isolates carried the $f l a C$ gene. They also reported that the $f l a C$ gene was widely distributed in other Vibrio spp. including $V$. anguillarum, $V$. alginolyticus, $V$. campbellii, $V$. fischeri, $V$. fluvialis, $V$. mimicus, $V$. natriegens and $V$. parahaemolyticus. Another study revealed that flaC was detected in $60 \%$ of the Vibrio in the Harveyi clade [21]. Similarly, the sequence diversity of flaC observed in this study coincided with a previous report [25], and flagella play an important role in infecting host because it increase the motility of bacteria for colonization, or act as adhesive component [26].

The thermolabile hemolysin gene tlh was previously used as species specific marker to identify $V$. parahaemolyticus [27]. However in this study, th recovered from non-parahaemolyticus strains showed highly similar sequence with those from $V$. parahaemolyticus. The results indicate that th cannot be used as species specific marker for detection of $V$. parahaemolyticus due to possible detection of false-positive results. Furthermore, previous study showed an increase in the environmental $V$. parahaemolyticus strains carrying the $t d h$ and/or trh genes in Malaysia [28]. Interestingly, all isolates in this study lacked the virulence genes associated pathogenic Vibrio of human, which are the $t d h$, trh, $h l y A$ and $t o x R_{\nu c}$ genes, indicating low potential risk for human health. On the other hand, higher percentage of pathogenic Vibrio were positive to trh (40\%) and $t d h(12.3 \%)$ was detected in aquatic animals in other studies [29, 30].

In general, similar virulence genes were widely distributed in the Harveyi clade, indicating that the genes are readily transferred among the Vibrionaceae species. This horizontal transferability of virulence genes might be due to their survival benefits in a variety of environments and host organisms [31].

Antibiotics are commonly used in fish farms either as feed additives, prophylaxis or therapy. Oxytetracycline, TE, quinolones, nitrofurans, potentiated sulfonamides, trimethoprim, sarafloxacin, flumequine and oxolinic acid are among the permissible antibiotics that have been used to combat vibriosis [32]. This study revealed that the Harveyi clade were highly resistance to AMP and VA. Similarly, all Vibrio isolates collected from Malaysian coastal area 
were resistant to AMP at the rate between 42 and $82 \%$ [33], including $100 \%$ of isolates from farmed fish [34]. The prevalence of AMP resistance in Vibrio isolates from marine environment is generally high, which probably due to the wide usage of AMP. Moreover, resistance to AMP or other penicillin were also well documented from environmental isolated Vibrio, ranging from 56 to $100 \%$ in China, Italy and U.S. [19, 35, 36].

FEP is one of the newer fourth generation cephalosporins [33]. While none of the isolates in this study showed resistance towards FEP, $84 \%$ of the isolates showed immediate sensitive towards this antibiotic. On the other hand, TE and nitrofurans were effective to inhibit the growth of Vibrio isolates in this study, thus can be used to treat Vibrio infection in Malaysian farm. However, prolonged and misused of antibiotics possess the danger of developing antibiotic resistant genes, that cause the Vibrio to develop resistance [13].

In this study, the prevalence of MAR strains of Vibrio was at the alarming rate. The results indicate that the MAR strains of Vibrio existed widely in the aquaculture farm in this country. Ransangan et al. [34] and You et al. [33] reported high prevalence of multiple antibiotic Vibrio recovered from coastal seawater in Malaysia. While there is limited documentation on the information of the use of antibiotics in Malaysian fish farming, emergence of MAR Vibrio strains due to excessive utilization of antibiotics has been reported in other countries [2, 19, 37, 38]. For example, high MAR index (0.4) of Harveyi clade strains causing scale drop and muscle necrosis disease in groupers was reported in China [19]. Moreover, $77.3 \%$ of $V$. parahaemolyticus isolated from oyster in Korea demonstrated MAR to at least three antibiotics, with highest MAR index of 0.75 in one isolate [18].

In general, high prevalence of isolates that were resistant to multiple antibiotics was observed in Pulau Ketam, one of the extensive mariculture farms in Malaysia. While no antibiotic was recorded being used for treatment at our sampling site in Pulau Ketam, the Vibrio with multiple antibiotic resistance can be easily transmitted from nearby farms that used antibiotic via water column. In addition, Vibrio spp. may acquire and carry antibiotic resistance genes by horizontal genetic transference from and to neighbouring microorganisms. Out of seven sampling site, only the hatchery in Port Dickson reported on the utilization of antibiotic to treat bacterial infection. The rapid increase in antibiotic resistance rendered the treatment to be more difficult. The use of antibiotics in aquaculture also impacts the frequencies of resistance in human pathogens [15, 37]. Therefore, calls for the reduction of antibiotic use has been done worldwide [38, 39].

Other methods of vibriosis control are urgently needed. In recent year, the disruption of quorum sensing has recently been suggested as a cost-effective and environmental friendly method [12]. Several bacteria, micro-algae, macro-algae and aquatic sponges have been shown to inhibit quorum sensing properties in pathogenic Vibrio particularly $V$. harveyi $[12,23]$. Given the wide distribution of quorum sensing regulated-gene in different Vibrio species found in this study, this method are promising to control the expression of virulence factors by different Vibrio species in aquaculture. In addition, immunostimulants, bacteriophage, vaccines and probiotics also have potentials to replace antibiotics in controlling and preventing vibriosis in fish farm [40].

\section{Conclusion}

In conclusion, low prevalence of virulence genes was detected in Vibrio spp. within the Harveyi clade in this study. However, majority of the isolates exhibited multiple resistance to tested antibiotics, highlighting the urgency for reducing the usage of antibiotic in fish farms. It is necessary to perform extensive studies on the spread of antibiotic resistance genes in Vibrio to understand the potential risk to public health. In the meantime, alternative non-antibiotic based methods such as quorum quenching and utilization of lytic bacteriophage for preventing and treating bacterial infections in fish farm are needed.

\section{Methods}

\section{Bacterial strains}

Large collection of Vibrio strains previously isolated from either healthy or diseased fish cultured in marine farm or hatchery were used in this study. The farm and hatchery included were intensive or semi-intensive farms culturing and producing finfish fry, including Asian seabass (Lates calcarifer), red snapper (Lutjanus sp.) and hybrid grouper (Epinephelus sp.). Seven sampling sites were selected as representative of important fish farming and fry producing area in Peninsular Malaysia; Pulau Ketam and Banting in Selangor, Port Dickson in Negeri Sembilan, Kuala Gula in Perak, Kukup in Johor, Kota Bharu in Kelantan, and Pulau Langkawi in Kedah (Table 1).

Identification of the Vibrio isolates were verified based on the partial sequencing of $\mathrm{pyrH}$ as described in previous reports [41, 42]. Based on the recovery rates, only four species of Vibrio were selected for this study. A total of 63 isolates representative of $V$. alginolyticus, $V$. 
Table 1 Number of Vibrio isolates, type and background information of farms and hatcheries selected in this study

\begin{tabular}{|c|c|c|c|c|c|c|c|c|c|c|}
\hline \multirow[t]{2}{*}{ Location } & \multicolumn{5}{|c|}{ No. of Vibrio isolates } & \multirow{2}{*}{$\begin{array}{l}\text { Type of sampling } \\
\text { sites }\end{array}$} & \multirow{2}{*}{$\begin{array}{l}\text { Diseases problem } \\
\text { encountered }\end{array}$} & \multirow{2}{*}{$\begin{array}{l}\text { Treatments } \\
\text { history }\end{array}$} & \multirow[t]{2}{*}{ Species of cultured fish } & \multirow[t]{2}{*}{ Stocking density } \\
\hline & $\overline{V A}$ & $\mathrm{VP}$ & $\mathrm{VH}$ & VC & Total & & & & & \\
\hline Pulau Ketam, Selangor & 21 & 6 & 8 & 5 & 40 & Farm & Bacteria, virus, parasite & Chemical & $\begin{array}{l}\text { Red snapper, hybrid } \\
\text { grouper, Asian seabass, } \\
\text { golden pompano }\end{array}$ & $300 \mathrm{fish} /$ cage \\
\hline Kuala Gula, Perak & 3 & 3 & - & 1 & 7 & Farm & Bacteria, parasite & Chemical & $\begin{array}{l}\text { Red snapper, hybrid } \\
\text { grouper, Asian seabass }\end{array}$ & $300 \mathrm{fish} /$ cage \\
\hline $\begin{array}{l}\text { Port Dickson, Negeri } \\
\text { Sembilan }\end{array}$ & 2 & 2 & - & 2 & 6 & Hatchery & Bacteria, virus & $\begin{array}{l}\text { Chemical, } \\
\text { antibiotic }\end{array}$ & Hybrid grouper & 400 fish/tank \\
\hline Pulau Langkawi, Kedah & 1 & 1 & - & - & 2 & Farm & Bacteria, virus & Chemical & Hybrid grouper & 1500 fish/cage \\
\hline Banting, Selangor & - & 2 & - & - & 2 & Hatchery & Bacteria & Chemical & Hybrid grouper & NA \\
\hline Kota Bharu, Kelantan & - & 3 & - & 1 & 4 & Hatchery & Bacteria & Chemical & Hybrid grouper & NA \\
\hline Kukup, Johor & - & 2 & - & - & 2 & Farm & Parasite & Freshwater & Hybrid grouper & 1000 fish/cage \\
\hline
\end{tabular}

VA Vibrio alginolyticus, VP Vibrio parahaemolyticus, VH Vibrio harveyi, VC Vibrio campbellii; -: no isolate, NA data not available

harveyi, $V$. parahaemolyticus and $V$. campbellii were analysed. Forty of the isolates were isolated either from Asian seabass, red snapper and hybrid grouper cultured in Pulau Ketam, Selangor. Another 23 Vibrio isolates were recovered from hybrid groupers cultured in farm or hatchery located in different states in Peninsular Malaysia (Table 1). The code, species name, source of isolation, clinical sign/s of the host, month and year of isolation, and geographical origin of the isolates as listed in Appendix 1. All isolates were kept in 20\% glycerol stock and stored at $-80^{\circ} \mathrm{C}$ for further analysis.

\section{Virulence genes detection}

All isolates were sub-cultured from glycerol stock onto Tryptic Soy Agar (TSA) (HiMedia, Mumbai, India), supplemented with $1.5 \% \mathrm{NaCl}$ and incubated at $30^{\circ} \mathrm{C}$ for $18 \mathrm{~h}$. Prior to PCR, genomic DNA of the isolates was extracted using Wizard Genomic DNA Purification Kit (Promega, WI, USA).

A total of nine virulence-associated genes (chiA, $v h p A, \operatorname{luxR}$, flaC, hlyA, toxR $R_{v c}$, th, tdh and trh) of Vibrio were detected by PCR amplification. The sequence of primers used are as listed in Table 2. PCR amplifications were performed in a final volume of $30 \mu \mathrm{L}$, which contained $1 \times \mathrm{PCR}$ buffer, $2 \mathrm{mM} \mathrm{MgCl} 2$, $200 \mathrm{uM}$ dNTPs, $10 \mathrm{pmol}$ of forward primer, $10 \mathrm{pmol}$ of reverse primer, $5 \mathrm{U} / \mu \mathrm{L}$ Taq polymerase and $100 \mathrm{ng}$ of template DNA (Promega). The amplification was performed under the following conditions: initial denaturation at $95^{\circ} \mathrm{C}$ for $5 \mathrm{~min}$, followed by 30 cycles of $95^{\circ} \mathrm{C}$ for $1 \mathrm{~min} ; 50^{\circ} \mathrm{C}$ for $1 \mathrm{~min}$ (chiA, vhpA and luxR), 55 for $1 \mathrm{~min}(f l a C), 60$ for $1 \mathrm{~min}$ (hlyA and tox $R_{\nu c}$ ) and $72{ }^{\circ} \mathrm{C}$ for $1 \mathrm{~min}$, and a final extension of $72{ }^{\circ} \mathrm{C}$ for $10 \mathrm{~min}$ using Eppendorf Mastercycler Nexus Thermal Cycler (Eppendorf, Hamburg, Germany). The amplification of $t$ th, trh and $t d h$ was performed under the following conditions: initial denaturation at $94{ }^{\circ} \mathrm{C}$ for $3 \mathrm{~min}$, followed by 30 cycles of $94{ }^{\circ} \mathrm{C}$ for $1 \mathrm{~min}$; 58 ${ }^{\circ} \mathrm{C}$ for $1 \mathrm{~min}$ and $72{ }^{\circ} \mathrm{C}$ for $1 \mathrm{~min}$, and a final extension of $72^{\circ} \mathrm{C}$ for $10 \mathrm{~min}$.

Amplified PCR products were visualised on 1.2\% agarose gel stained with ethidium bromide, run at $90 \mathrm{~V}$ for $40 \mathrm{~min}$, and photographed using a gel documented system. The confirmation of the presence of genes were by partial sequencing (FirstBase, Kuala Lumpur, Malaysia) and BLAST comparison with GenBank (http://blast.ncbi. nlm.nih.gov/). Following multiple alignment of genes with their closed taxa by CLUSTAL W method, neighbour-joining trees were constructed using the Kimura 2-parameter model with MEGA version 7.0 with bootstraps of 1000 replicates [43].

\section{Antibiotic sensitivity testings}

The antibiotics sensitivity of the isolates were examined by the disc diffusion methods [44]. A total of 18 representative antimicrobial agents (Oxoid, London, UK), including penicillins (ampicillin (AMP): $10 \mu \mathrm{g}$; penicillin G (P): 10 units), cephems (cefotaxime (CTX): $30 \mu \mathrm{g}$; cefepime (FEP): $30 \mu \mathrm{g}$; cephalothin (KF): $30 \mu \mathrm{g}$ ), aminoglycosides (gentamycin $(\mathrm{CN}): 10 \mu \mathrm{g}$; kanamycin $(\mathrm{K}): 30 \mu$; streptomycin (S): $10 \mu \mathrm{g}$ ), and others such as nalidixic acid (NA): $30 \mu \mathrm{g}$; trimethoprim/sulfamethoxazole (SXT): 1.25/23.75 $\mu \mathrm{g}$; chloramphenicol (C): $30 \mu \mathrm{g}$; nitrofurantoin (F): $300 \mu \mathrm{g}$; ciprofloxacin (CIP): $5 \mu \mathrm{g}$; tetracycline (TE): $30 \mu \mathrm{g}$; erythromycin (E): $15 \mu \mathrm{g}$; and vancomycin (VA): $30 \mu \mathrm{g}$ were used.

Following incubation for $18-24 \mathrm{~h}$, the isolates were then inoculated in sterile saline water to achieve turbidity equivalent to 0.5 MacFarland standard. The broth were evenly swabbed onto Mueller Hinton 
Table 2 Virulence factors, sequence of primers, references and expected amplicon size of target gene used in this study

\begin{tabular}{|c|c|c|c|c|}
\hline Gene & Virulence factor & Primer sequence $\left(5^{\prime}-3^{\prime}\right)$ & Reference & Amplicon size (bp) \\
\hline chiA & Chitinase & F: GGAAGATGGCGTGATTGACT R: GGCATCAATTTCCCAAGAGA & [21] & 232 \\
\hline vhpA & Metalloprotease & F: CTGAACGACGCCCATTATTT R:CGCTGACACATCAAGGCTAA & [21] & 201 \\
\hline luxR & Quorum sensing factors & F: ATGGACTCAATTGCAAAGAG R: TTAGTGATGTTCACGGTTGT & [21] & 618 \\
\hline flac & Flagella of $V$. anguillarum & F: AAATCATTCCAAATCGGTGC R: TCTTTGATTCGGCTCTTA & [25] & 580 \\
\hline hlyA & Haemolysin of $V$. cholera & F: GGCAAACAGCGAAACAAATAC C R: CTCAGCGGGCTAATACGGTTTA & [48] & 738 \\
\hline toxR $_{\mathrm{ve}}$ & Toxin of $V$. cholera & F: ATG TTC GGA TTA GGA CAC R: TAC TCA CAC ACT TTG ATG GC & [49] & 883 \\
\hline th & $\begin{array}{l}\text { Thermolabile haemolysin of } \\
\text { V. parahaemolyticus }\end{array}$ & F: AAAGCGGATTATGCAGAAGCACTG R: GCTACTTTCTAGCATTTTCTCTGC & [27] & 450 \\
\hline$t d h$ & $\begin{array}{l}\text { Thermostable direct haemolysin } \\
\text { (TDH) of } V \text {. parahaemolyticus }\end{array}$ & F: GTAAAGGTCTCTGACTITTGGAC R: TGGAATAGAACCTTCATCTTCACC & [27] & 269 \\
\hline $\operatorname{trh}$ & $\begin{array}{l}\text { TDH-related haemolysin }(\mathrm{TRH}) \\
\text { of } V \text {. parahaemolyticus }\end{array}$ & F: TTGGCTTCGATATTTTCAGTATCT R: CATAACAAACATATGCCCATTTCCG & [27] & 500 \\
\hline
\end{tabular}

agar (HiMedia) supplemented with $1 \%$ of $\mathrm{NaCl}$ [45]. Antibiotic discs were aseptically placed on the swabbed plates. The plates were then incubated at $35^{\circ} \mathrm{C}$ for $16-18 \mathrm{~h}$, and the clearing zone was recorded. Testing was confirmed in duplicate. The resistance profiles (resistant, intermediate or susceptible) were assigned using criteria described by CLSI [44, 46] and Bauer et al. [47]. The multiple antibiotic resistance (MAR) index was determined for each isolate [20]. Table 3 summarized the list of antibiotics and the zone diameter interpretive criteria used in this study.

Table 3 List of antibiotics used in this study

\begin{tabular}{|c|c|c|c|c|c|c|}
\hline \multirow[t]{2}{*}{ Antimicrobial class } & \multirow[t]{2}{*}{ Antimicrobial agent } & \multirow[t]{2}{*}{ Code } & \multirow[t]{2}{*}{ Dose } & \multicolumn{3}{|c|}{ Zone diameter interpretive criteria } \\
\hline & & & & Sensitive & Intermediate & Resistance \\
\hline \multicolumn{7}{|l|}{ Cell envelope antibiotics } \\
\hline \multirow[t]{2}{*}{ Penicillins } & Ampicillin & AMP & $10 \mu \mathrm{g}$ & $\geq 17$ & $14-16$ & 13 \\
\hline & Penicillin G & $P$ & 10 unit & $\geq 29$ & $21-28$ & $\leq 20$ \\
\hline \multirow[t]{3}{*}{ Cephems } & Cefotaxime & CTX & $30 \mu \mathrm{g}$ & $\geq 26$ & $19-24$ & $\leq 18$ \\
\hline & Cefepime & FEP & $30 \mu \mathrm{g}$ & $\geq 25$ & $19-24$ & $\leq 18$ \\
\hline & Cephalothin & KF & $30 \mu \mathrm{g}$ & $\geq 18$ & $15-17$ & $\leq 14$ \\
\hline \multicolumn{7}{|l|}{ Protein synthesis inhibitors } \\
\hline \multirow[t]{3}{*}{ Aminoglycosides } & Gentamycin & $\mathrm{CN}$ & $10 \mu \mathrm{g}$ & $\geq 15$ & $12-14$ & $\leq 11$ \\
\hline & Kanamycin & K & $30 \mu \mathrm{g}$ & $\geq 18$ & $14-17$ & $\leq 13$ \\
\hline & Streptomycin & $\mathrm{S}$ & $10 \mu \mathrm{g}$ & $\geq 15$ & $12-14$ & $\leq 11$ \\
\hline Tetracyclines & Tetracycline & $\mathrm{TE}$ & $30 \mu \mathrm{g}$ & $\geq$ & & $\leq$ \\
\hline \multicolumn{7}{|l|}{ Nucleic acid inhibitors } \\
\hline \multirow[t]{2}{*}{ Quinolones } & Ciprofloxacin & $\mathrm{CIP}$ & $5 \mu \mathrm{g}$ & $\geq 21$ & $16-20$ & $\leq 15$ \\
\hline & Nalidixic acid & NA & $30 \mu \mathrm{g}$ & $\geq 19$ & $14-18$ & $\leq 13$ \\
\hline DNA inhibitors & Nitrofurantoin & $F$ & $300 \mu \mathrm{g}$ & $\geq 17$ & $15-16$ & $\leq 14$ \\
\hline Potentiated sulfonamides & $\begin{array}{l}\text { Sulfamethoxazole/ } \\
\text { trimethoprim }\end{array}$ & SXT & $1.25 / 23.75 \mu \mathrm{g}$ & $\geq 16$ & $11-15$ & $\leq 10$ \\
\hline \multicolumn{7}{|l|}{ Phenicol derivatives } \\
\hline Chloramphenicols & Chloramphenicol & C & $30 \mu \mathrm{g}$ & $\geq 18$ & $13-17$ & $\leq 12$ \\
\hline \multicolumn{7}{|l|}{ Transpeptidation/Translocation } \\
\hline Macrolides & Erythromycin & $E$ & $15 \mu g$ & $\geq 18$ & $14-17$ & $\leq 13$ \\
\hline \multicolumn{7}{|l|}{ Glycopeptide } \\
\hline Polypeptides & Vancomycin & VA & $30 \mu \mathrm{g}$ & $\geq 12$ & $10-11$ & $\leq 9$ \\
\hline
\end{tabular}

Zone diameter interpretive criteria were referred to the performance standards proposed by Clinical and Laboratory Standards Institute [44, 46], with the exception for erythromycin and vancomycin which referred to Bauer et al. [47] 


\section{Appendix}

Table 4 Details on list of isolates used in this study

\begin{tabular}{|c|c|c|c|c|c|c|}
\hline No. & Code & Species & Source of isolation & Clinical sign/s of host & $\begin{array}{l}\text { Month and year } \\
\text { of isolation }\end{array}$ & Geographical origin \\
\hline 1 & SNA 92-L & V.A & Liver of red snapper & $\begin{array}{l}\text { Rotten caudal fin, blind left eye } \\
\text { and pale liver }\end{array}$ & Dec 2016 & Pulau Ketam, Selangor \\
\hline 2 & GRO 99-E & V.A & Eye of hybrid grouper & $\begin{array}{l}\text { Lesion on body, haemorrhagic } \\
\text { liver and kidney and rotten } \\
\text { caudal fin }\end{array}$ & Dec 2016 & Pulau Ketam, Selangor \\
\hline 3 & GRO 102-K & V.A & Kidney of hybrid grouper & Blind left eye and pale liver & Jan 2017 & Pulau Ketam, Selangor \\
\hline 4 & SEA 107-S & V.A & Skin mucus of Asian seabass & Haemorrhagic liver & Jan 2017 & Pulau Ketam, Selangor \\
\hline 5 & SNA 109-S1 & V.A & Skin mucus of red snapper & $\begin{array}{l}\text { Haemorrhagic liver and } \\
\text { kidney }\end{array}$ & Jan 2017 & Pulau Ketam, Selangor \\
\hline 6 & SEA 144-L & V.A & Liver of Asian seabass & $\begin{array}{l}\text { Pale liver and haemorrhagic } \\
\text { kidney }\end{array}$ & Jan 2017 & Pulau Ketam, Selangor \\
\hline 7 & SNA 144-L & V.A & Liver of red snapper & $\begin{array}{l}\text { Blind left eye, pale liver and pale } \\
\text { kidney }\end{array}$ & Feb 2017 & Pulau Ketam, Selangor \\
\hline 8 & GRO 144-E1 & V.A & Eye of hybrid grouper & $\begin{array}{l}\text { Lesion on body, blind left eye } \\
\text { and haemorrhagic kidney }\end{array}$ & Feb 2017 & Pulau Ketam, Selangor \\
\hline 9 & GRO 162-S & V.A & Skin mucus of hybrid grouper & Pale liver & Feb 2017 & Pulau Ketam, Selangor \\
\hline 10 & SNA 165-E & V.A & Eye of red snapper & Pale liver & Jan 2017 & Pulau Ketam, Selangor \\
\hline 11 & GRO 198-S1 & V.A & Skin lesion on hybrid grouper & Lesion on pectoral fin & Apr 2017 & Pulau Ketam, Selangor \\
\hline 12 & SNA 199-E1 & V.A & Eye of red snapper & No symptom & Apr 2017 & Pulau Ketam, Selangor \\
\hline 13 & SEA 205-E1 & V.A & Eye of Asian seabass & No symptom & May 2017 & Pulau Ketam, Selangor \\
\hline 14 & GRO 208-K1 & V.A & Kidney of hybrid grouper & Lesion on all fins & May 2017 & Pulau Ketam, Selangor \\
\hline 15 & SNA 212-S1 & V.A & Skin mucus of red snapper & Bulging eye & May 2017 & Pulau Ketam, Selangor \\
\hline 16 & GRO 223-S & V.A & Skin mucus of hybrid grouper & $\begin{array}{l}\text { Lesion on body and all fins, } \\
\text { and haemorrhagic liver }\end{array}$ & May 2017 & Pulau Ketam, Selangor \\
\hline 17 & SNA 226-E & V. A & Eye of red snapper & Haemorrhage liver & May 2017 & Pulau Ketam, Selangor \\
\hline 18 & SNA 266-S & V.A & Skin mucus on red snapper & $\begin{array}{l}\text { Rotten caudal fin and pale } \\
\text { liver }\end{array}$ & May 2017 & Pulau Ketam, Selangor \\
\hline 19 & GRO 268-E & V. A & Eye of hybrid grouper & Haemorrhagic liver & May 2017 & Pulau Ketam, Selangor \\
\hline 20 & GRO 286-L1 & V.A & Liver of hybrid grouper & $\begin{array}{l}\text { Ulcer on body and } \\
\text { haemorrhagic liver }\end{array}$ & Aug 2017 & Pulau Ketam, Selangor \\
\hline 21 & SNA 297-S1 & V.A & Skin mucus of red snapper & No symptom & Aug 2017 & Pulau Ketam, Selangor \\
\hline 22 & PKG28 & V. A & Spleen of hybrid grouper & Lesion on operculum and fins & Nov 2017 & Kuala Gula, Perak \\
\hline 23 & PKGS29 & V.A & Spleen of hybrid grouper & Lesion on operculum & Nov 2017 & Kuala Gula, Perak \\
\hline 24 & PKG29 & V. A & Liver of hybrid grouper & Lesion on operculum & Mar 2017 & Kuala Gula, Perak \\
\hline 25 & NL24 & V.A & Liver of hybrid grouper & $\begin{array}{l}\text { Lesion on body and fins, and } \\
\text { pale liver }\end{array}$ & Dis 2017 & Port Dickson, Negeri Sembilan \\
\hline 26 & NS24 & V.A & Spleen of hybrid grouper & $\begin{array}{l}\text { Lesion on body and fins, and } \\
\text { pale liver }\end{array}$ & Dis 2017 & Port Dickson, Negeri Sembilan \\
\hline 27 & LL6 & V. A & Liver of hybrid grouper & No symptom & Mar 2017 & Pulau Langkawi, Kedah \\
\hline 28 & SNA 147-L2 & V.P & Liver of red snapper & $\begin{array}{l}\text { Haemorrhagic liver and } \\
\text { kidney }\end{array}$ & Feb 2017 & Pulau Ketam, Selangor \\
\hline 29 & GRO 180-K1 & V.P & Kidney of hybrid grouper & No symptom & Apr 2017 & Pulau Ketam, Selangor \\
\hline 30 & SEA 196-S1 & V.P & Skin lesion on Asian seabass & Lesion on body & Apr 2017 & Pulau Ketam, Selangor \\
\hline 31 & GRO 251-K1 & V.P & Kidney of hybrid grouper & $\begin{array}{l}\text { Ulcer on body and fins, } \\
\text { and pale liver }\end{array}$ & July 2017 & Pulau Ketam, Selangor \\
\hline 32 & SEA 252-E1 & V.P & Eye of Asian seabass & Rotten caudal fin & July 2017 & Pulau Ketam, Selangor \\
\hline 33 & GRO 286-E1 & V.P & Eye of hybrid grouper & $\begin{array}{l}\text { Ulcer on body and } \\
\text { haemorrhagic liver }\end{array}$ & Aug 2017 & Pulau Ketam, Selangor \\
\hline
\end{tabular}


Table 4 Details on list of isolates used in this study (Continued)

\begin{tabular}{|c|c|c|c|c|c|c|}
\hline No. & Code & Species & Source of isolation & Clinical sign/s of host & $\begin{array}{l}\text { Month and year } \\
\text { of isolation }\end{array}$ & Geographical origin \\
\hline 34 & BK2G2 & V.P & Kidney of hybrid grouper & $\begin{array}{l}\text { Lesion on operculum, pale } \\
\text { liver and enlarged spleen }\end{array}$ & Nov 2016 & Kuala Gula, Perak \\
\hline 35 & BK3G2 & V.P & Kidney of hybrid grouper & Pale liver & Nov 2016, & Banting, Selangor \\
\hline 36 & PKGL4 & V.P & Liver of hybrid grouper & Lesion on body & Nov 2017 & Kuala Gula, Perak \\
\hline 37 & PKGS11 & V.P & Spleen of hybrid grouper & No symptom & Nov 2017 & Kuala Gula, Perak \\
\hline 38 & PKGL27 & V.P & Liver of hybrid grouper & Lesion on fins & Nov 2017 & Kuala Gula, Perak \\
\hline 39 & NK6 & V.P & Kidney of hybrid grouper & $\begin{array}{l}\text { Lesion on body and fins, } \\
\text { and pale liver }\end{array}$ & Dis 2017 & Port Dickson, Negeri Sembilan \\
\hline 40 & NS8 & V.P & Spleen of hybrid grouper & Lesion on body and fins & Dis 2017 & Port Dickson, Negeri Sembilan \\
\hline 41 & LK14 & V.P & Kidney of hybrid grouper & No symptom & Aug 2017 & Pulau Langkawi, Kedah \\
\hline 42 & KK3 & V.P & Kidney of hybrid grouper & $\begin{array}{l}\text { Lesion on operculum, and } \\
\text { enlarged spleen and liver }\end{array}$ & Sept 2017 & Kota Bharu, Kelantan \\
\hline 43 & $\mathrm{KL4}$ & V.P & Liver of hybrid grouper & $\begin{array}{l}\text { Lesion on body, and } \\
\text { enlarged spleen and liver }\end{array}$ & Sept 2017 & Kota Bharu, Kelantan \\
\hline 44 & KL17 & V.P & Liver of hybrid grouper & $\begin{array}{l}\text { Lesion on body, eye opacity, } \\
\text { pale liver and enlarged } \\
\text { spleen }\end{array}$ & Sept 2017 & Kota Bharu, Kelantan \\
\hline 45 & JS14 & V.P & Spleen of hybrid grouper & No symptom & Dis 2017 & Kukup, Johor \\
\hline 46 & $J S 24$ & V.P & Spleen of hybrid grouper & No symptom & Dis 2017 & Kukup, Johor \\
\hline 47 & SEA 131-K1 & V.H & Kidney of Asian seabass & $\begin{array}{l}\text { Haemorrhagic kidney } \\
\text { and liver }\end{array}$ & Feb 2017 & Pulau Ketam, Selangor \\
\hline 48 & SNA 143-L1 & V.H & Liver of red snapper & $\begin{array}{l}\text { Rotten caudal fin and } \\
\text { haemorrhagic kidney }\end{array}$ & Feb 2017 & Pulau Ketam, Selangor \\
\hline 49 & GRO 154-E1 & V.H & Eye of hybrid grouper & $\begin{array}{l}\text { Lesion on pelvic fin and } \\
\text { severely pale liver }\end{array}$ & Mar 2017 & Pulau Ketam, Selangor \\
\hline 50 & SEA 166-E & V.H & Eye of Asian seabass & $\begin{array}{l}\text { Lesion on body and } \\
\text { haemorrhagic liver }\end{array}$ & Apr 2017 & Pulau Ketam, Selangor \\
\hline 51 & SEA 192-S1 & V.H & Skin mucus of Asian seabass & Haemorrhagic liver & Apr 2017 & Pulau Ketam, Selangor \\
\hline 52 & GRO 200-L2 & V.H & Liver of hybrid grouper & No symptom & Apr 2017 & Pulau Ketam, Selangor \\
\hline 53 & SEA 207-S1 & V.H & Skin mucus of Asian seabass & $\begin{array}{l}\text { Haemorrhagic liver and } \\
\text { kidney }\end{array}$ & May 2017 & Pulau Ketam, Selangor \\
\hline 54 & SNA 272-S2 & V.H & Skin mucus of red snapper & Pale liver & July 2017 & Pulau Ketam, Selangor \\
\hline 55 & SEA 178-K1 & V.C & Kidney of Asian seabass & $\begin{array}{l}\text { Haemorrhagic liver and } \\
\text { kidney }\end{array}$ & Apr 2017 & Pulau Ketam, Selangor \\
\hline 56 & GRO 186-K1 & V.C & Kidney of hybrid grouper & Lesion of all fins & Apr 2017 & Pulau Ketam, Selangor \\
\hline 57 & SNA 244-S2 & V.C & Skin mucus of red snapper & $\begin{array}{l}\text { Haemorrhagic liver and } \\
\text { kidney }\end{array}$ & June 2017 & Pulau Ketam, Selangor \\
\hline 58 & SEA 206-S1 & V.C & Skin mucus of Asian seabass & Haemorrhage liver & May 2017 & Pulau Ketam, Selangor \\
\hline 59 & GRO 230-L1 & V.C & Liver of hybrid grouper & $\begin{array}{l}\text { Lesion on whole body, } \\
\text { pale liver and haemorrhage } \\
\text { kidney }\end{array}$ & June 2017 & Pulau Ketam, Selangor \\
\hline 60 & PKGL28 & V. C & Liver of hybrid grouper & $\begin{array}{l}\text { Lesion on operculum and } \\
\text { dorsal fin }\end{array}$ & Nov 2017 & Kuala Gula, Perak \\
\hline 61 & NS26 & V.C & Spleen of hybrid grouper & $\begin{array}{l}\text { Lesion on body and } \\
\text { discoloration }\end{array}$ & Dis 2017 & Port Dickson, Negeri Sembilan \\
\hline 62 & NS12 & V.C & Spleen of hybrid grouper & Lesion on body and fins & Dis 2017 & Port Dickson, Negeri Sembilan \\
\hline 63 & KL28 & V.C & Liver of hybrid grouper & $\begin{array}{l}\text { Lesion on body and fins, } \\
\text { pale liver and spleen } \\
\text { enlarged }\end{array}$ & Sept 2017 & Kota Bharu, Kelantan \\
\hline
\end{tabular}




\section{Abbreviations}

AMP: Ampicillin; C: Chloramphenicol; CIP: Ciprofloxacin; CN: Gentamycin; CTX: Cefotaxime; E: Erythromycin; F: Nitrofurantoin; FEP: Cefepime; K: Kanamycin; KF: Cephalothin; MAR: Multiple antibiotic resistance; NA: Nalidixic acid; P: Penicillin G; S: Streptomycin; SXT: Trimethoprim/ sulfamethoxazole; TE: Tetracycline; TSA: Tryptic soy agar; VA: Vancomycin

\section{Acknowledgements}

The authors are grateful to farmers that helping the sampling activities.

\section{Funding}

This work was partially supported by the Universiti Putra Malaysia (GP-IPB/ 2016/9484101 and GP-IPS/2018/9619200) and the Higher Institution Centre of Excellence, the Ministry of Higher Education (Vote no.: 6369100). The funding sources had no role in study design; in the collection, analysis and interpretation of data; in the writing of the report; and in the decision to submit the article for publication.

\section{Availability of data and materials}

The datasets used and analysed during the current study are available from the corresponding author on reasonable request.

\section{Authors' contributions}

NM, MNAA, ISMY and NAZ conducted the bacterial sampling activities. NM and NAZ conducted laboratory works. NM, MNAA and NSN conducted data analyses. NM drafted the manuscript. MNAA, ISMY, MZS, MM and NSN were involved in critical reading, editing and final approval of the submitted version.

\section{Ethics approval}

Not applicable.

\section{Consent for publication}

Not applicable.

\section{Competing interests}

The authors declare that they have no competing interests.

\section{Publisher's Note}

Springer Nature remains neutral with regard to jurisdictional claims in published maps and institutional affiliations.

\begin{abstract}
Author details
${ }^{1}$ Department of Biology, Faculty of Science, Universiti Putra Malaysia, 43400 UPM Serdang, Selangor, Malaysia. ${ }^{2}$ Department of Veterinary Laboratory Diagnosis, Faculty of Veterinary Medicine, Universiti Putra Malaysia, 43400 UPM Serdang, Selangor, Malaysia. ${ }^{3}$ Department of Aquaculture, Faculty of Agriculture, Universiti Putra Malaysia, 43400 UPM Serdang, Selangor, Malaysia. ${ }^{4}$ Laboratory of Marine Biotechnology, Institute of Bioscience, Universiti Putra Malaysia, 43400 UPM Serdang, Selangor, Malaysia. ${ }^{5}$ Centre for Craniofacial Diagnostics and Biosciences, Faculty of Dentistry, Universiti Kebangsaan Malaysia, Jalan Raja Muda Abdul Aziz, 50300 Kuala Lumpur, Malaysia.
\end{abstract}

\section{Received: 13 December 2018 Accepted: 10 May 2019}

\section{Published online: 28 May 2019}

\section{References}

1. Bunpa S, Sermwittayawong N, Vuddhakul V. Extracellular enzymes produced by Vibrio alginolyticus isolated from environments and diseased aquatic animals. Procedia Chem. 2016;18:12-7.

2. Xu Y, Wang C, Zhang G, Tian J, Liu Y, Shen X, Feng J. ISCR2 is associated with the dissemination of multiple resistance genes among Vibrio spp. and Pseudoalteromonas spp. isolated from farmed fish. Arch Microbiol. 2017 ; 199(6):891-6.

3. Khouadja S, Lamari F, Bakhrouf A. Characterization of Vibrio parahaemolyticus isolated from farmed sea bass (Dicentrarchus labrax) during disease outbreaks. Int Aquatic Res. 2013:5(1):13.

4. Abdullah A, Ramli R, Ridzuan MSM, Murni M, Hashim S, Sudirwan F, Abdullah SZ, Mansor NN, Amira S, Zamri-Saad M, Amal MNA. The presence of Vibrionaceae, Betanodavirus and Iridovirus in marine cage-cultured fish: role of fish size, water physicochemical parameters and relationships among the pathogens. Aquaculture Rep. 2017;7:57-65.

5. Dong HT, Taengphu S, Sangsuriya P, Charoensapsri W, Phiwsaiya K, Sornwatana T, Khunrae P, Rattanarojpong T, Senapin S. Recovery of Vibrio harveyi from scale drop and muscle necrosis disease in farmed barramundi, Lates calcarifer in Vietnam. Aquaculture. 2017:473:89-96.

6. Nurliyana M, Fauzul-Aidil MR, Amal MNA, Zamri-Saad M, Ina-Salwany MY, Nor-Amalina Z, Shaqinah NN. Natural concurrent infection of Vibrio harveyi and $V$. alginolyticus in cultured hybrid groupers in Malaysia. J Aquat Anim Health. 2019;31:88-96.

7. Aguirre-Guzmán G, Mejia Ruíz H, Ascencio F. A review of extracellular virulence product of Vibrio species important in diseases of cultivated shrimp. Aquac Res. 2004:35(15):1395-404.

8. Nakhamchik A, Wilde C, Rowe-Magnus DA. Cyclic-di-GMP regulates extracellular polysaccharide production, biofilm formation, and rugose colony development by Vibrio vulnificus. Appl Environ Microbiol. 2008;74(13) 4199-209.

9. Rønneseth A, Castillo D, D'Alvise P, Tønnesen $\varnothing$, Haugland G, Grotkjær T, Engell-Sørensen K, Nørremark L, Bergh $\varnothing$, Wergeland HI, Gram L. Comparative assessment of Vibrio virulence in marine fish larvae. J Fish Dis. 2017:40:1373-85.

10. Frans I, Michiels CW, Bossier P, Willems KA, Lievens B, Rediers H. Vibrio anguillarum as a fish pathogen: virulence factors, diagnosis and prevention. J Fish Dis. 2011;34(9):643-61.

11. Austin $\mathrm{B}$, Zhang $\mathrm{XH}$. Vibrio harveyi: a significant pathogen of marine vertebrates and invertebrates. Lett Appl Microbiol. 2006;43(2):119-24.

12. Natrah FMI, Defoirdt T, Sorgeloos P, Bossier P. Disruption of bacterial cell-tocell communication by marine organisms and its relevance to aquaculture. Mar Biotechnol. 2011;13(2):109-26.

13. Cabello FC, Godfrey HP, Tomova A, Ivanova L, Dolz H, Millanao A, Buschmann $\mathrm{AH}$. Antimicrobial use in aquaculture re-examined: its relevance to antimicrobial resistance and to animal and human health. Environ Microbiol. 2013;15:1917-42

14. Letchumanan V, Pusparajah P, Tan LTH, Yin WF, Lee LH, Chan K. Occurrence and antibiotic resistance of Vibrio parahaemolyticus from shellfish in Selangor, Malaysia. Front Microbiol. 2015:6:1417.

15. Elmahdi S, DaSilva LV, Parveen S. Antibiotic resistance of Vibrio parahaemolyticus and Vibrio vulnificus in various countries: a review. Food Microbiol. 2016;57:128-34.

16. Heng SP, Letchumanan V, Deng CY, Ab Mutalib NS, Khan TM, Chuah LH, Chan KG, Goh BH, Pusparajah P, Lee LH. Vibrio vulnificus: an environmental and clinical burden. Front Microbiol. 2017;8:997.

17. Lee LH, Ab Mutalib NS, Law JWF, Wong SH, Letchumanan V. Discovery on antibiotic resistance patterns of Vibrio parahaemolyticus in Selangor reveals carbapenemase producing Vibrio parahaemolyticus in marine and freshwater fish. Front Microbiol. 2018;9:2513.

18. Kang $\mathrm{CH}$, Shin $\mathrm{Y}$, Jang $\mathrm{S}, \mathrm{Yu} H, \mathrm{Kim} \mathrm{S}, \mathrm{An} \mathrm{S}$, So JS. Characterization of Vibrio parahaemolyticus isolated from oysters in Korea: resistance to various antibiotics and prevalence of virulence genes. Marine Poll Bull. 2017;118(12):261-6.

19. Zhu ZM, Dong CF, Weng SP, He JG. The high prevalence of pathogenic Vibrio harveyi with multiple antibiotic resistance in scale drop and muscle necrosis disease of the hybrid grouper, Epinephelus fuscoguttatus ( $(+) \times \mathrm{E}$. lanceolatus (ふै), in China. J Fish Dis. 2017;19(4):191-8.

20. Krumperman $\mathrm{PH}$. Multiple antibiotic indexing of $E$. coli to identify high-risk sources of fecal contamination of foods. Appl Environ Microbiol. 1985;46: 165-70.

21. Ruwandeepika HAD, Defoirdt T, Bhowmick PP, Shekar M, Bossier P, Karunasagar I. Presence of typical and atypical virulence genes in vibrio isolates belonging to the Harveyi clade. J Appl Microbiol. 2010;109(3): 888-99.

22. Hasegawa $\mathrm{H}$, Lind EJ, Boin MA, Häse CC. The extracellular metalloprotease of Vibrio tubiashii is a major virulence factor for pacific oyster (Crassostrea gigas) larvae. Appl Environ Microbiol. 2008;74(13):4101-10.

23. Defoirdt T, Boon N, Sorgeloos P, Verstraete W, Bossier P. Quorum sensing and quorum quenching in Vibrio harveyi: lessons learned from in vivo work. ISME J. 2008;2:19-26.

24. Croxatto A, Chalker VJ, Lauritz J, Jass J, Hardman A, Williams P, Camara M, Milton DL. VanT, a homologue of Vibrio harveyi LuXR, regulates serine, metalloprotease, pigment, and biofilm production in Vibrio anguillarum. J Bacteriol. 2002;184(6):1617-29. 
25. Bai F, Pang L, Qi Z, Chen J, Austin B, Zhang XH. Distribution of five vibrio virulence-related genes among Vibrio harveyi isolates. J Gen Appl Microbiol. 2008;54(1):71-8.

26. Chen Q, Yan Q, Wang K, Zhuang Z, Wang X. Portal of entry for pathogenic Vibrio alginolyticus into large yellow croaker Pseudosciaena crocea, and characteristics of bacterial adhesion to mucus. Dis Aquat Org. 2008;80(3): $181-8$.

27. Bej AK, Patterson DP, Brasher CW, Vickery MCL, Jones DD, Kaysner CA. Detection of total and hemolysin-producing Vibrio parahaemolyticus in shellfish using multiplex PCR amplification of $t l, t d h$ and trh. J Microbiol Methods. 1999;36:215-25.

28. Sujeewa AK, Norrakiah AS, Laina M. Prevalence of toxic genes of Vibrio parahaemolyticus in shrimps (Penaeus monodon) and culture environment. Int Food Res J. 2009;16:89-95.

29. Al-Othrubi SM, Kqueen CY, Mirhosseini H, Hadi YA, Radu S. Antibiotic resistance of Vibrio parahaemolyticus isolated from cockles and shrimp sea food marketed in Selangor, Malaysia. Clin Microbiol. 2014;3:148-54.

30. Letchumanan V, Yin WF, Lee LH, Chan KG. Prevalence and antimicrobial susceptibility of Vibrio parahaemolyticus isolated from retail shrimps in Malaysia. Front Microbiol. 2015;6:33.

31. Nakamura $Y$, Itoh T, Matsuda H, Gojobori T. Biased biological functions of horizontally transferred genes in prokaryotic genomes. Nat Genet. 2004;36: 760-6.

32. Rico A, Satapornvanit K, Haque MM, Min J, Nguyen PT, Telfer TC, van den Brink PJ. Use of chemicals and biological products in Asian aquaculture and their potential environmental risks: a critical review. Rev Aquacult. 2012;4: 75-93.

33. You KG, Bong CW, Lee CW. Antibiotic resistance and plasmid profiling of Vibrio spp. in tropical waters of peninsular Malaysia. Environ Monit Assess. 2016;188(3):171.

34. Ransangan J, Imm LKL, Lal TM, Sade A. Phenotypic characterization and antibiotic susceptibility of Vibrio spp. isolated from aquaculture waters on the west coast of Sabah, Malaysia. Int J Res Pure Appl Microbiol. 2013;3(3): 58-66.

35. Zanetti S, Spanu T, Deriu A, Romano L, Sechi LA, Fadda G. In vitro susceptibility of Vibrio spp. isolated from the environment. Int J Antimicrob Agents. 2001;17(5):407-9.

36. Fernández-Delgado M, Suárez P, Giner S, Sanz V, Peña J, Sánchez D, GarcíaAmado MA. Occurrence and virulence properties of Vibrio and Salinivibrio isolates from tropical lagoons of the southern Caribbean Sea. Antonie Van Leeuwenhoek. 2017;110(6):833-41.

37. Igbinosa EO. Detection and antimicrobial resistance of Vibrio isolates in aquaculture environments: implications for public health. Microb Drug Resist. 2016;22(3):238-45

38. Nguyen HNK, Van $T \mathrm{H}$, Coloe PJ. Antibiotic resistance associated with aquaculture in Vietnam. Microbiol Australia. 2016;37(3):108-11.

39. WHO. Report of a joint FAO/OIE/WHO Expert Consultation on Antimicrobial Use in Aquaculture and Antimicrobial Resistance. Seoul: World Health Organization; 2006.

40. Ina-Salwany MY, Nurhidayu A, Aslah M, Fathin-Amirah M, Aslizah MA, Amal MNA, Hisae K, Sayaka M, Tomoo S, Zamri-Saad M. Vibriosis in fish: a review on disease development and prevention. J Aquat Anim Health. 2019;31:322.

41. Nurliyana M, Amal MNA, Zamri-Saad M, Ina-Salwany MY. Possible transmission routes of Vibrio spp. in tropical cage-cultured marine fishes. Lett Appl Microbiol. 2019;68(6):485-96.

42. Nurliyana M, Mustafa M, Amal MNA, Mohd-Zamri S, Ina-Salwany MY, Al-saari $\mathrm{N}$. Environmental factors associated with the presence of Vibrionaceae in tropical cage-cultured marine fishes. J Aquat Anim Health. 2019. https://doi. org/10.1002/aah.10062

43. Kumar S, Stecher G, Tamura K. MEGA 7: molecular evolutionary genetics analysis version 7.0 for bigger dataset. Mol Biol Evol. 2016;33(7):1870-4.

44. CLSI. Methods for dilution antimicrobial diltion and disk susceptibility testing of infrequently isolated or fastidious bacteria; approved guideline2nd ed., CLSI document M45-A2. 2010. Clinical and laboratory standards institute, Wayne, Pennsylvania 19087, USA

45. Ottaviani D, Bacchiocchi I, Masini L, Leoni F, Carraturo A, Giammarioli M, Sbaraglia G. Antimicrobial susceptibility of potentially pathogenic halophilic vibrios isolated from sea- food. Int J Antimicrob Agents. 2001;18:135-40.
46. CLSI. Performance standards for antimicrobial susceptibility testing; twentythird informational supplement, CLSI document M100-S23. 2013. Clinical and laboratory standards institute, Wayne, Pennsylvania 19087, USA.

47. Bauer AW, Kirby WMM, Shenis JC, Turck M. Antibiotic susceptibility testing by a standardized single disk method. Am J Clin Pathol. 1966;45:493.

48. Saravanan V, Sanath KH, Karunasagar I, Karunasagar I. Putative virulence genes of Vibrio cholerae from seafoods and the coastal environment of Southwest India. Int J Food Microbiol. 2007;119:329-33.

49. Miller VL, Taylor RK, Mekalanos JJ. Cholera toxin transcriptional activator ToxR is a transmembrane DNA binding protein. Cell. 1987;48:271-9.
Ready to submit your research? Choose BMC and benefit from:

- fast, convenient online submission

- thorough peer review by experienced researchers in your field

- rapid publication on acceptance

- support for research data, including large and complex data types

- gold Open Access which fosters wider collaboration and increased citations

- maximum visibility for your research: over $100 \mathrm{M}$ website views per year

At BMC, research is always in progress.

Learn more biomedcentral.com/submissions 